\title{
Egészségkommunikáció az 1960-as években
}

\section{Health communication in the 1960s}

\author{
Szerző: Kutai Orsolya $\square$ \\ Gottsegen György Országos Kardiológiai Intézet
}

Beküldve: 2019. 12. 12.

doi: 10.24365/ef.v60i5.548

Kulcsszavak: egészségkommunikáció; prevenció

Keywords: health communication; prevention

Az Egészségfejlesztés szerkesztősége a lap fennállásának 60. évfordulója alkalmából felkutatta a folyóirat legkorábbi lapszámait, hogy különböző témákban megjelent közleményeket dolgozzon fel. 1960-tól jelenik meg a folyóirat, így a 60-as és 70-es évek lapszámaiból válogattunk az akkori nevén Egészségügyi Felvilágosítás című szaklapból.

Jelen közlemény az egészségkommunikáció témájában kíván tallózni a 60 évvel ezelőtti cikkekből. Napjainkban már szinte elképzelhetetlen, néha megmosolyogtató kommunikációs tartalmakkal is találkozhatunk az írásokban, ezekből ismertetünk most néhány példát.

Az Egészségügyi felvilágosítási propagandaanyagok készítése címú írás részletesen ismerteti a különböző egészségügyi felvilágosító kiadványok elkészítésének szabályait, kezdve a tartalmi kérdésektől, stílustól egészen a nyomdai kivitelezéssel kapcsolatos tudnivalókig. ${ }^{1}$ A szerző által fontosnak ítélt, a szakmai tartalomra vonatkozó javaslatok napjainkban is érvényesek, ezek közül a legfontosabbak:

- pozitív megközelítés: „...valamennyi egészségügyi felvilágosító kiadvány csakis optimista jellegű lehet. Feltétlenül elkerülendő mindazon kifejezési mód, módszer, mely félelemkeltésre, az emberek elijesztésére alapoz..."

- közérthetőség: „....valamennyi egészségügyi felvilágosító kiadványnak magas színvonalúnak, mégis népszerúnek, azaz közérthetőnek kell lennie..., ...a laikus szemszögéből épüljön fel. Óvakodni kell minden szakmai 'túlzástól', orvosi műszavak használatától, diagnosztizálástól, gyógyszerelésre vonatkozó utasítástól."

- differenciáltság: „...vegye figyelembe azt, akinek szól. Ugyanazt az ismeretanyagot másként kell a falusi és másként a városi lakosság számára közölni, ugyancsak másként az iskolában vagy az üzemben."

- gyakorlatiasság: „Az elmélyítendő anyagot lehetőleg gyakorlati példával támassza alá a kiadvány és gyakorlati tennivalókra vonatkozó következtetést vonjon le."

A fenti irányelvek ugyanúgy érvényesek a mai modern egészségkommunikációs tartalmak készítése során is.

A lap egyik alapítójának, Métneki Jánosnak 1970ben megjelent cikke a tömegkommunikáció és a kiscsoportos egészségnevelés szerepét, hatékonyságát, esetleges azzal kapcsolatos problémákat 
ismerteti. ${ }^{2}$ A tömegkommunikációs eszközök között a televízió, a sajtó és a rádió szerepel, hiszen internethasználatról ebben az időszakban még nem beszélhetünk. A közlemény megállapítja, hogy a tömegkommunikáció egyre nagyobb szerepet játszik a mindennapi életben, akkori adatok szerint ezek az eszközök a lakosság 90\%-át érik el, közülük 20-25\%-nak pedig ezek a kizárólagos tájékozódási forrásai.

A TV, rádió és sajtón keresztüli kommunikáció hiányosságaként azt nevezi meg a szerző, hogy azok hatása sem korlátlan, automatikusan nem változtatnak az emberek nézetén, hozzáállásán, szemben a "hagyományosabb”, kiscsoportos egészségneveléssel, azaz a különböző személyes találkozáson alapuló, elsősorban rendezvények alkalmával végzett tájékoztató munkával. A tömegkommunikáció nagy előnye nyilvánvalóan az, hogy széles célközönséghez juttatja el az információt, azonban nem specifikus, hanem inkább általánosabb témákban bizonyulhat jó csatornának. Kiemeli az írás a véleményirányító személyek (opinion leader), azaz az orvosok, egészségügyi dolgozók szerepét a célzott kommunikációban, akik közvetlen befolyásuk révén tudnak egyénekre ható, tartós hatást elérni.

A cikk összefoglalásként azt állapítja meg, hogy bár a hagyományos, személyes egészségnevelés nem hagyható figyelmen kívül, de a tömegkommunikációs csatornáknak is nagyon fontos szerepük van. Nem versenyről van szó, hanem inkább arra kell hangsúlyt fektetni, hogy ezek a csatornák miként tudják a leghatékonyabban kiegészíteni egymást, tehát a kommunikáció mindkét formájának helye van.

Napjainkban sincs ez másképp. Manapság nehézséget jelent még az is, hogy az interneten keresztül már bármilyen témában percek alatt rengeteg információhoz juthatunk, a szakmailag is helytálló tartalmak mellett számos tudományos hátteret nélkülöző információ ér el bennünket. Fontos, hogy mindig hiteles forrásból tájékozódjunk.

A téves információk közlésének veszélyével akkoriban is foglalkoztak a szakemberek, egy 1966-os közlemény a sajtóban és a televízióban előforduló „félre-világosításról” ír. ${ }^{3}$ A cikk több példát mutat be a lakosság félretájékoztatására, amelyek veszélyt is jelenthetnek, amennyiben azt az olvasók komolyan veszik.

A szerző javaslata ma is megállja a helyét, miszerint „....csakis olyan egészségügyi cikkek jelennek meg, amelyektől az olvasó nem válik hipochonderré. Olyan írásokat közöljünk, amelyek nem javasolnak gyógymódokat, nem ígérnek csodálatos javulást."

A kommunikációs eszközök között igen nagy szerepe volt régebben a plakátoknak, ezzel a témával számos cikk foglalkozik. Érdekes adat, hogy az Egészségügyi Felvilágosítási Központ' 1957 és 1960 között összesen 73 témában, 644.712 plakátot adott ki. A most ismertetett közlemény szerint a jó plakát: ${ }^{4,5}$

- figyelemfelkeltő;

- érdeklődést keltő;

- érthető;

- emlékezni fognak rá;

- érzelemformáló;

- mozgósító.

Két, ebben az időszakban készült felvilágosító plakát esetében a szakemberek egy kísérletet is elvégeztek. Azt vizsgálták, hogy az „újabb” grafikai múvészeti irány mennyire lehet hatásos a plakátok sikerességében, azaz mennyire érik el a kívánt célt részletesebb magyarázó szöveges feliratok nélkül: a szemlélők megértik-e az üzeneteket, cselekvésre motiválják-e őket, továbbá, hogy pozitív vagy negatív hatást váltanak ki. A két kiválasztott plakát modern grafikai ábrázolással készült: „nagy színfoltokkal, nagyvonalú, kifejező ábrázolással, szembeszökő, rövid szöveggel" (az eredeti szövegeket eltávolították):

1. plakát témája: gyümölcsfogyasztás, [1. ábra]

2. plakát témája: a légy, mint fertőző betegségek terjesztője. [2. ábra]

A kísérletet 200 fős, egészséges populáción végezték el, akiknek megmutatták a plakátokat, majd a vizsgálat lebonyolítása során kérdőíves és megfigyelési módszert alkalmaztak.

Összegezve az eredmények:

- Mindkét plakát figyelemfelkeltőnek bizonyult.

- Jelenlegi formájukban a plakátok csak 53\%-os, illetve 38,5\%-os arányban voltak

\footnotetext{
'Az Egészségügyi Minisztérium irányítása alatt álló, 1958-ban megalakult országos hatáskörű intézmény az egészségnevelés szervező, irányító, tudományos kutatásainak területén.
} 
érthetőek, tehát az üzenet nem érte el maradéktalanul a célját.

- A grafikai megjelenítés - főleg a 2. plakát esetében - nem váltott ki pozitív érzelmeket, ez pedig csökkenti a kép mozgósító hatását.

1. ábra: „Mosatlan gyümölcs betegséget terjeszt” címü plakát

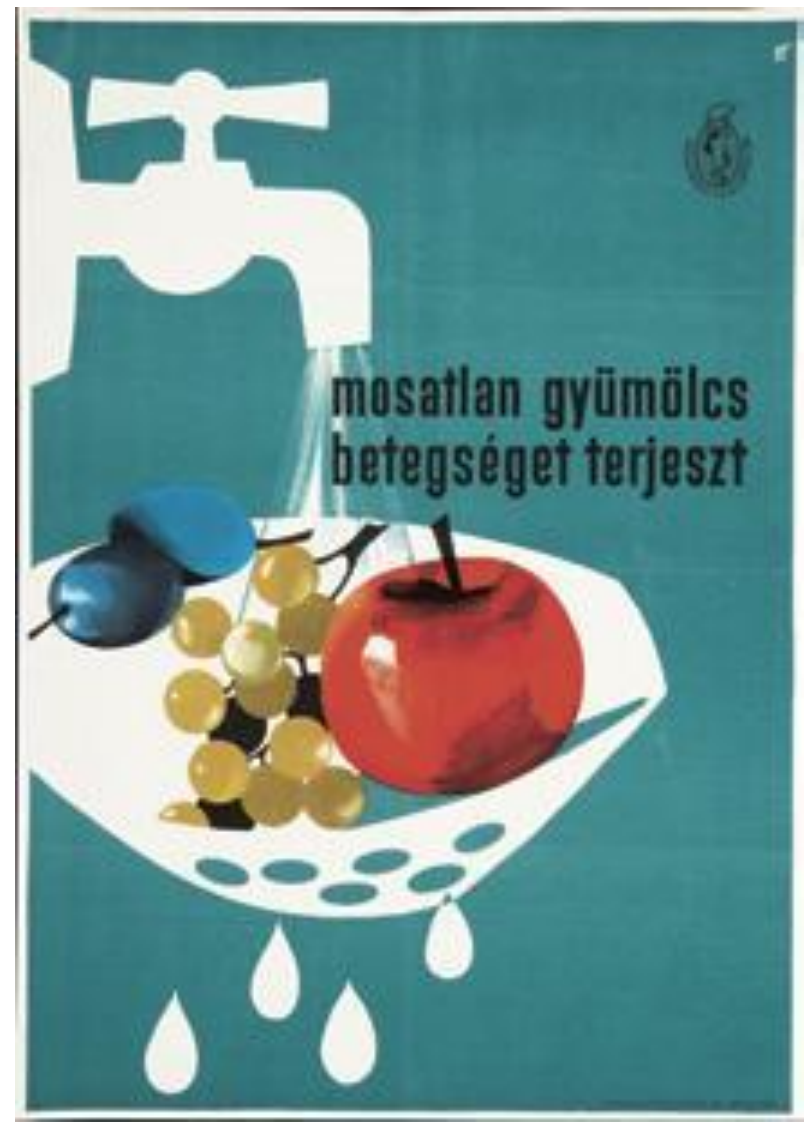

Forrás: http://artmagazin.hu/
Módosítási javaslatok a felmérés alapján: a modern ábrázolási forma jó, a színeket valószerübbé kell tenni, a mondanivaló megértéséhez fontos a képi megjelenítés és a szöveg közötti egyértelmű összefüggés, valamint a kategorikus kijelentések, felszólítások használata.
2. ábra: „Ellenségünk” címü plakát

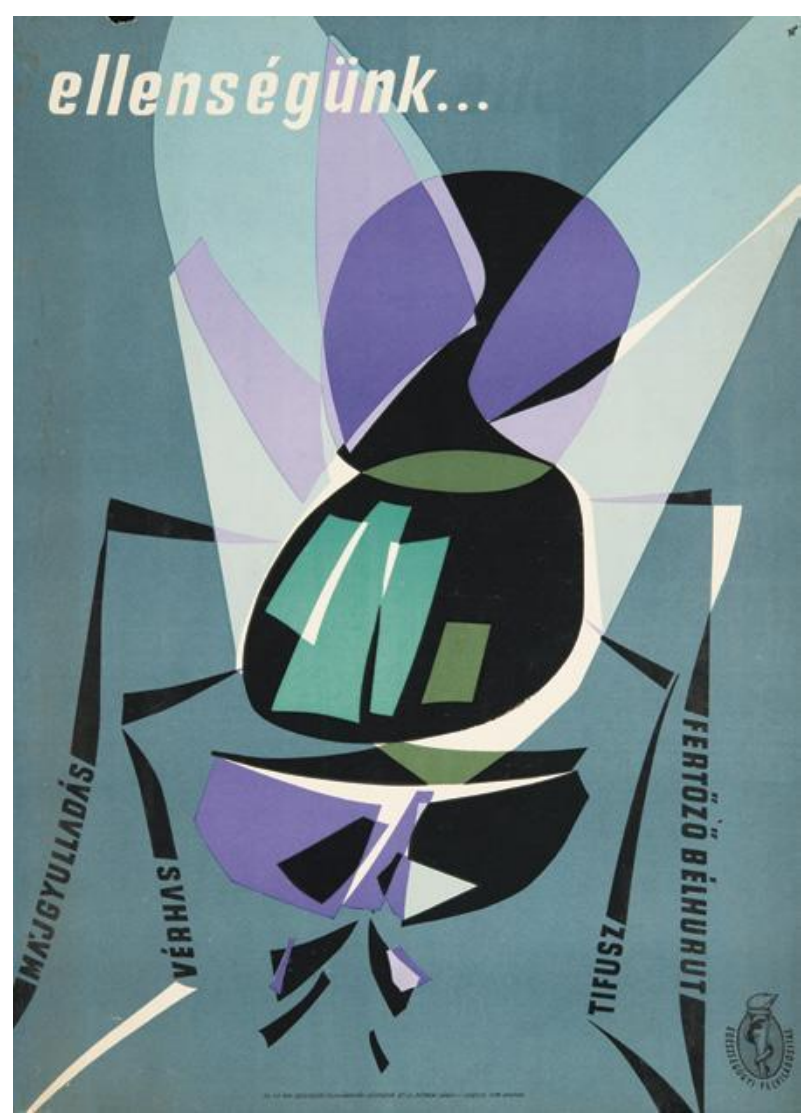

Forrás: http://artmagazin.hu/

vonatkozó szakmai irányok, inkább a minket körülvevő környezet, a kommunikációs eszközök változtak meg jelentősen az elmúlt 60 évben.
A feldogozott cikkek alapján elmondható, hogy alapjaiban nem változtak meg az egészségfejlesztő, egészségkommunikációs tartalmak előállítására

Végül néhány korabeli szovjet egészségfejlesztő/egészségnevelő plakát: ${ }^{6}$ [3. ábra-6. ábra] 
3. ábra: „Gyakrabban állitson be étrendjébe fözeléket, zöldséget" címü plakát

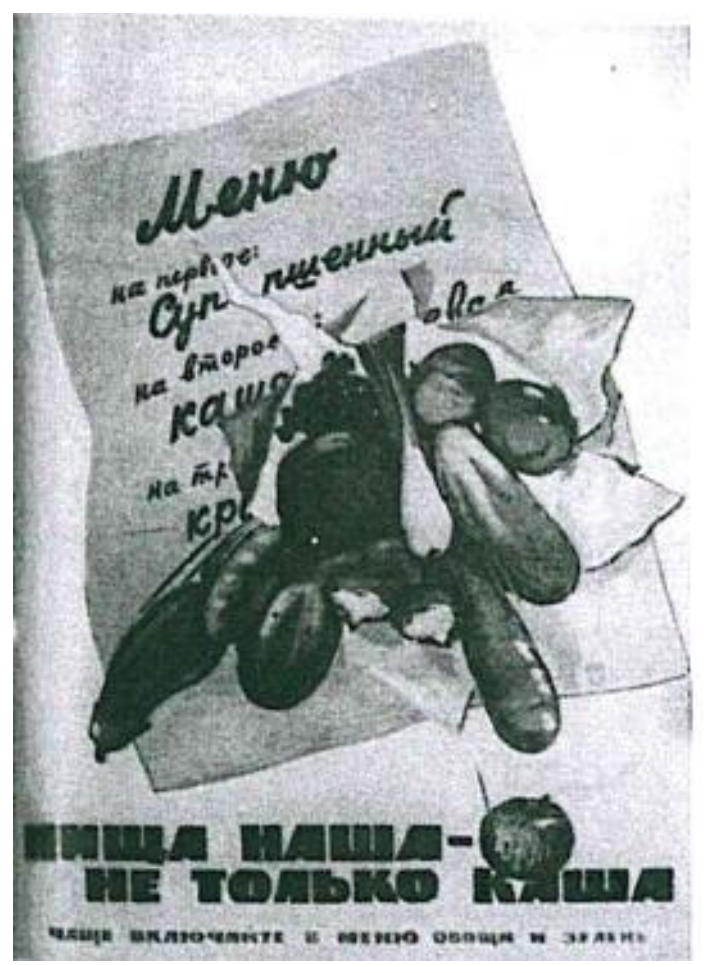

Forrás: Országos Széchenyi Könyvtár

5. ábra: „Amikor a bor bemegy - az ész kimegy!” címü plakát

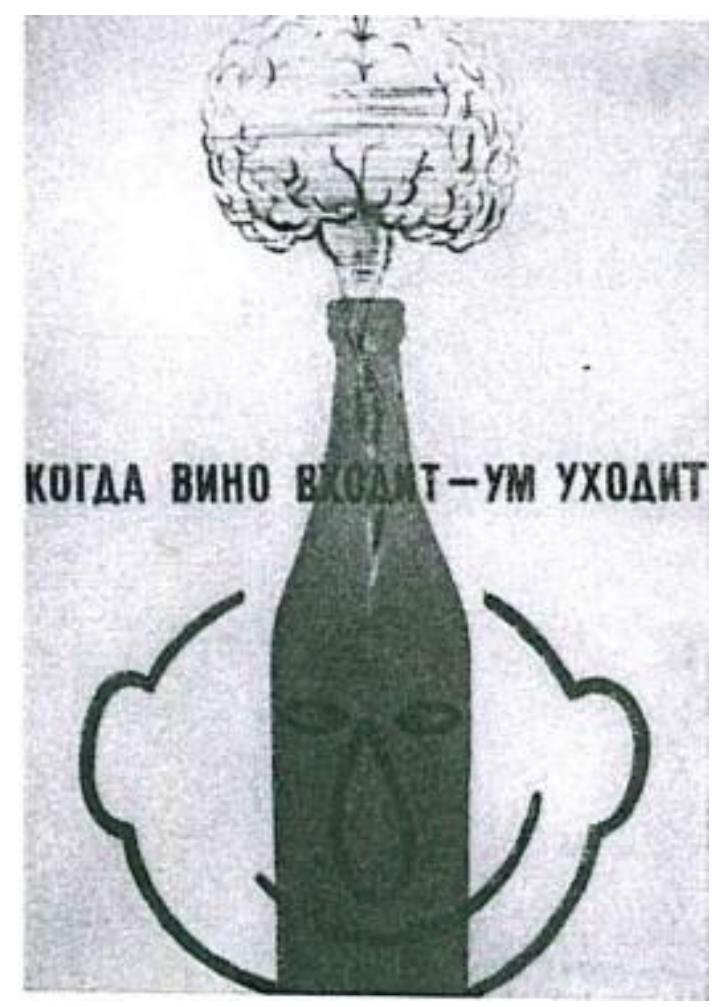

Forrás: Országos Széchenyi Könyvtár
4. ábra: „Munkahelyi torna különösen fontos a szalag melletti munkáknál" címü plakát

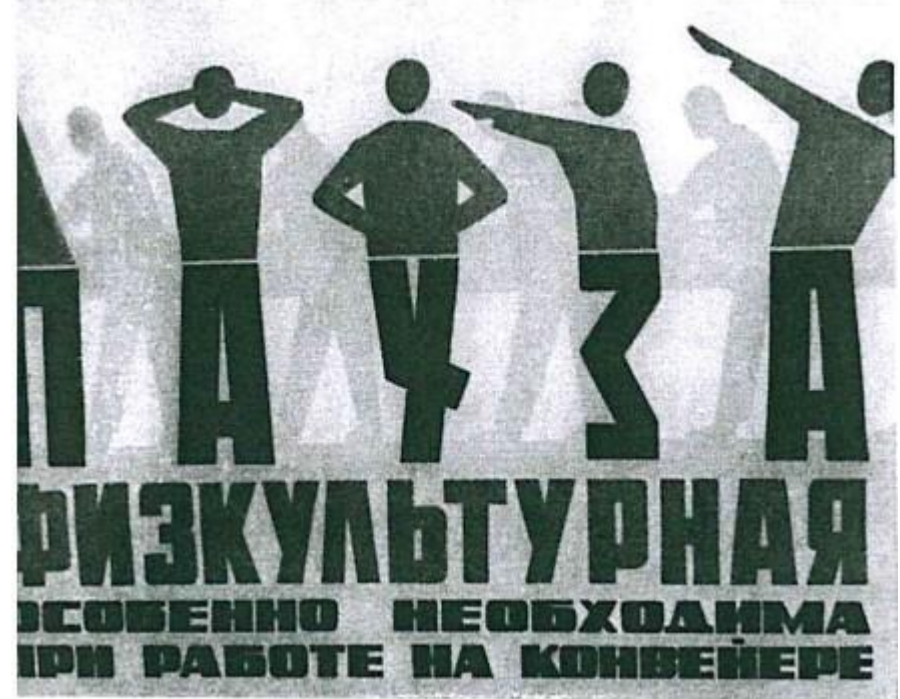

Forrás: Országos Széchenyi Könyvtár

6. ábra: Szovjet plakát alapján készült magyar kiadás

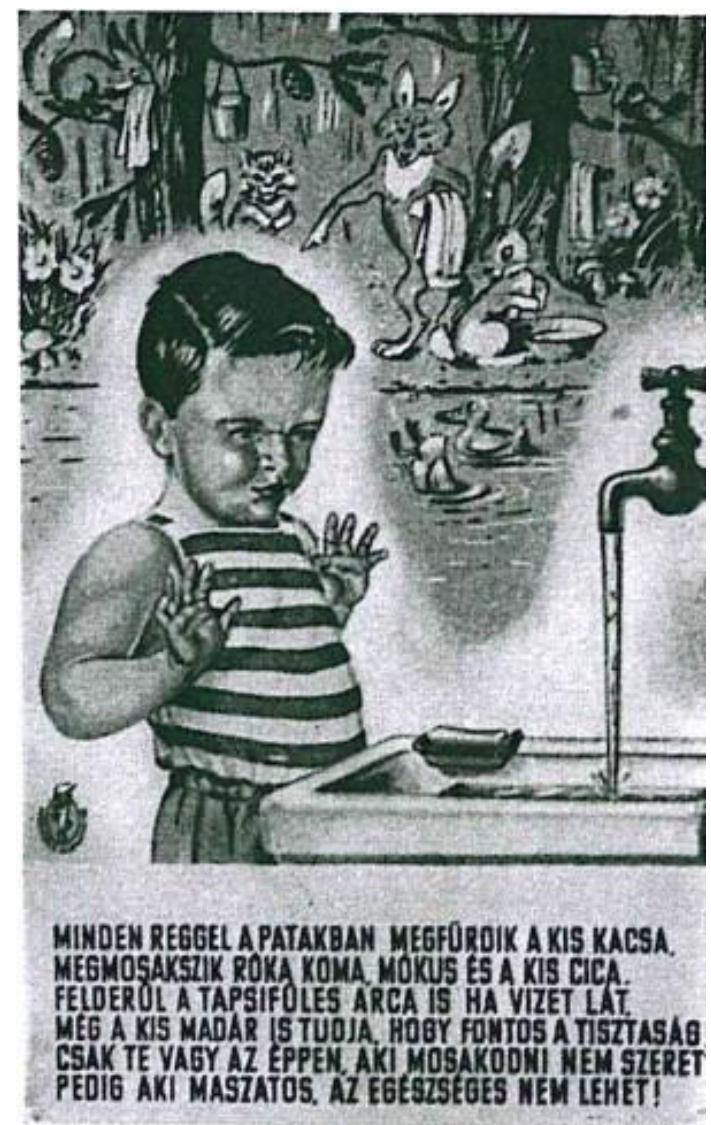

Forrás: Országos Széchenyi Könyvtár 


\section{HIVATKOZÁSOK}

${ }^{1}$ Székely L. Egészségügyi felvilágosítási propagandaanyagok készítése. Egészségügyi felvilágosítás. 1963;2:109-112

2 Métneki J. Tömegkommunikáció vagy kiscsoportos egészségnevelés? Egészségügyi felvilágosítás. 1970;11:152-156

${ }^{3}$ Veres P. Egészségügyi „félre-világosítás” a napi sajtóban. 1966;2:80-81

${ }^{4}$ Métneki J. Intézetünkről. Nemzeti Egészségfejlesztési Intézet honlapja http://regi.oefi.hu/tortenet.htm (Elérve: 2019. 12. 12.)

${ }^{5}$ Székely L. Egészségügyi felvilágosító plakátjaink hatásfokának értékelése. Egészségügyi felvilágosítás. 1965;3: 142-158

${ }^{6}$ Plakátreprodukciók a Szovjetunió ötvenéves egészségvédelmi és egészségnevelési tevékenységéből. Egészségügyi felvilágosítás. 1967;8:261-264 